\title{
PENGARUH PENGGUNAAN TEPUNG KUNYIT (Curcuma domestica Val.) DAN LAMA PENYIMPANAN TERHADAP KUALITAS SOSIS IKAN TENGGIRI (Scomberomorus sp.)
}

\author{
THE EFFECT FOR USE OF TURMINE FLOUR (Curcuma domestica \\ Val.) AND LONG STORAGE OF QUALITY MACKEREL FISH \\ (Scomberomorus sp.) SAUSAGES
}

\author{
Syaifuddin ${ }^{1^{*}}$ \\ ${ }^{1}$ Program Studi Teknologi Pengolahan Hasil Laut, Politeknik Palu \\ Jln. Sinarkemuning 1 No. 1A Palu 94118 Sulawesi Tengah, Indonesia
}

\begin{abstract}
ABSTRAK
Penelitian ini bertujuan untuk mengetahui pengaruh pemberian level tepung kunyit dan lama penyimpanan terhadap mutu mikrobiologi, mutu sensori dan mutu kimia sosis ikan tenggiri. Metode yang digunakan adalah penelitian deskriptif untuk mengamati jumlah total koloni bakteri dan kapang, sedangkan penelitian experimental dengan menggunakan Rancangan Acak Kelompok (RAK) pola faktorial untuk menganalisis uji sensori. Rancangan Acak Lengkap (RAL) pola faktorial untuk menganalisis uji kadar air dan $\mathrm{pH}$. Hasil penelitian menunjukan pemberian tepung kunyit dapat menghambat bakteri dan kapang selama 12 jam. Pengujian sensori menunjukan terdapat interaksi antara perlakuan level tepung kunyit dan lama penyimpanan. Pengujian kimia menunjukan lama penyimpanan dapat menyebabkan fluktuasi kadar air. Uji $\mathrm{pH}$ menunjukan level tepung kunyit dapat meningkatkan nilai $\mathrm{pH}$, dan nilai $\mathrm{pH}$ menurun selama penyimpanan. Kesimpulan penelitian bahwa level tepung kunyit dan lama penyimpanan mempengaruhi mutu mikroba sosis. Interaksi antara level tepung kunyit dan lama penyimpanan memberikan pengaruh terhadap rasa dan tekstur sosis ikan selama penyimpanan dengan menghambat pertumbuhan mikroba sehingga dapat mempertahankan dari penurunan mutu. level tepung kunyit dan lama penyimpanan mempengaruhi mutu kimia sosis.
\end{abstract}

Kata kunci : sosis ikan, kunyit, lama penyimpanan

\begin{abstract}
This study aims to determine the effect of giving levels of turmeric flour and storage time on microbiological quality, sensory quality and chemical quality of mackerel fish sausages. The method used in this research is descriptive research used to observe the total number of bacterial colonies and molds, while experimental research using Factorial randomized block design (RBD) for analyzing sensory tests. Completely Randomized Design (CRD) factorial pattern for analyzing water content and $\mathrm{pH}$ tests. The results showed the administration of turmeric flour can inhibit bacteria and mold for 12 hours. Sensory testing showed an interaction between the level of turmeric flour treatment and storage time. Chemical testing shows the storage time can cause fluctuations in water content. The $\mathrm{pH}$ test shows the level of turmeric flour can increase the $\mathrm{pH}$ value, and the $\mathrm{pH}$ value will decrease during storage. The conclusion of the study is that the level of turmeric flour and storage time affect the quality of sausage microbes. The interaction between the level of turmeric flour and the length of storage has an influence on the taste and texture of fish sausages during storage by inhibiting the growth of microbes so as to maintain quality degradation. levels of turmeric flour and storage duration affect the chemical quality of sausages
\end{abstract}

Key word: Sausage fish; turmeric; storage time

\footnotetext{
${ }^{*}$ Penulis Korespondensi.

E-mail: syaifuuddin02@gmail.com

Telp: 082346801667
} 


\section{Pendahuluan}

Sosis ikan merupakan salah satu teknologi produksi dan pengawetan ikan. Pengawetan sosis bertujuan untuk mempertahankan kualitas dan lama penyimpanan sosis dengan menghambat laju penurunan mutu, sehingga dengan adanya pengawetan dapat menekan pertumbuhan mikroorganisme penyebab kebusukan atau mencegah proses oksidasi sosis selama penyimpanan. Pengawetan sosis dengan cara pengasapan bertujuan untuk memberikan aroma dan mengawetkan dengan mencegah oksidasi lemak dan mengurangi kadar air pada sosis. Namun pengawetan sosis dengan cara pengasapan belum dapat dikatakan baik untuk kesehatan karena dapat mengandung zat karsinogen.

Selain dengan cara pengasapan, sosis juga dapat diawetkan dengan penambahan bahan kimia seperti nitrit. Menurut Cahyadi (2009), penggunaan maksimum pengawet nitrit di dalam produk daging olahan yaitu sebesar $125 \mathrm{mg} / \mathrm{kg}$. Konsumsi nitrit yang berlebihan dapat membahayakan kesehatan, baik yang bersifat langsung, yaitu keracunan, maupun yang bersifat tidak langsung, yaitu bersifat karsinogenik.

Kunyit (Curcuma domestica Val.) merupakan salah satu bahan alami yang dapat digunakan sebagai bahan pengawet makanan karena mengandung senyawa kurkumin yang bersifat antimikroba. Kunyit juga dapat memberikan warna kuning dan citarasa baru pada sosis ikan tenggiri hingga dapat menarik minat konsumen. Menurut Purwani $d k k$, (2012) kunyit dimanfaatkan sebagai bahan pengawet alami yang dapat memperpanjang waktu simpan makanan, karena mengandung kurkumin yang bersifat antimikroba.

Berdasarkan hal diatas telah dilakukan penelitian untuk melihat pengaruh penggunaan kunyit sebagai pengawet alami dan lama penyimpanan yang berbeda terhadap kualitas sosis ikan tenggiri yang disimpan pada suhu ruang.

\section{Metode Penelitian}

Jenis penelitian ini terdiri atas penelitian deskriptif dan penelitian experimental. Penelitian deskriptif digunakan untuk mengamati jumlah total koloni bakteri dan kapang, sedangkan penelitian experimental dengan menggunakan Rancangan Acak Kelompok (RAK) pola faktorial untuk menganalisis uji sensori. Rancangan Acak Lengkap (RAL) pola faktorial untuk menganalisis uji kadar air dan $\mathrm{pH}$. Faktor pertama adalah pemberian tepung kunyit pada sosis ikan yang terdiri dari empat level, dan faktor kedua lama penyimpanan sosis ikan yang terdiri dari empat taraf.

Penelitian ini di Laboratorium Teknologi Hasil Ternak Universitas Tadulako. Peralatan yang digunakan dalam penelitian ini adalah blender, ayakan tepung, mixer, kompor, dandang, pisau, mesin penepung, oven. Bahan yang digunakan yaitu daging ikan tenggiri, tepung tapioka, isolate protein kedelai, bawang putih, bawang merah, tepung kunyit, air, putih telur, lada bubuk, garam, casing sosis, dan gula halus.

\begin{tabular}{lc}
\multicolumn{2}{c}{ Tabel 1. Formulasi sosis ikan tenggiri } \\
\hline \multicolumn{1}{c}{ Bahan } & Jumlah \\
\hline Daging Ikan Tenggiri(g) & 1000 \\
Garam (g) & 16 \\
Air (ml) & 200 \\
Bawang Putih (g) & 10 \\
Bawang Merah (g) & 30 \\
Lada Bubuk (g) & 4 \\
Putih telur (butir) & 4 \\
Gula Halus (g) & 16 \\
Isolate Protein Kedelai (g) & 60 \\
Tepung Tapioka (g) & 90 \\
Tepung Kunyit & Sesuai \\
(g/bobot daging ikan) & Perlakuan \\
\hline
\end{tabular}

Parameter yang di uji dalam penelitian ini adalah Pengujian mikroba menggunakan media Nutrient Agar (NA) dan Media Potato Dextrose Agar (PDA) bertujuan untuk mengetahui jumlah total koloni bakteri dan total koloni kapang yang terdapat pada sosis ikan tenggiri yang diberi level tepung kunyit dan lama penyimpanan yang berbeda. Jumlah koloni mikroba pada produk sosis ikan dapat dihitung dengan menggunakan rumus :

$$
\mathrm{N}=\frac{\sum \mathrm{C}}{[(1 \times \mathrm{n} 1)+(0,1 \times \mathrm{n} 2) \times(\mathrm{d})}
$$

Pengujian sensori terhadap sosis ikan tenggiri meliputi aroma, warna, tekstur, dan rasa, berdasarkan tingkat kesukaan panelis ( 25 orang).

Uji kimia yang di uji dalam penelitian ini adalah Penentuan $\mathrm{pH}$ sosis yang dilakukan 
dengan menggunakan $\mathrm{pH}$ meter dan pengujian kadar air dengan menggunakan persamaan (AOAC, 1995) sebagai berikut :

$$
\text { Kadar Air }=\frac{A-B}{A} \times 100 \%
$$

\section{Hasil dan Pembahasan}

\section{Total Koloni Bakteri}

Berdasarkan hasil pengamatan sosis ikan tenggiri dengan pemberian tepung kunyit menunjukan adanya perbedaan total koloni bakteri pada setiap perlakuan disajikan dalam Tabel 2.

Tabel 2. Jumlah total koloni bakteri pada sosis ikan tenggiri dengan level tepung kunyit dan lama penyimpanan yang berbeda.

\begin{tabular}{lcccc}
\hline \multirow{2}{*}{$\begin{array}{c}\text { Level tepung } \\
\text { kunyit (\%) }\end{array}$} & \multicolumn{4}{c}{ Lama Penyimpanan (Jam) } \\
\cline { 2 - 5 } & $0(\mathrm{~W} 1)$ & $\begin{array}{c}12 \\
(\mathrm{~W} 2)\end{array}$ & $\begin{array}{c}24 \\
(\mathrm{~W} 3)\end{array}$ & $\begin{array}{c}36 \\
(\mathrm{~W} 4)\end{array}$ \\
\hline Kunyit 0 (K1) & $4 \times 10^{2}$ & $8 \times 10^{5}$ & Tbud & Tbud \\
Kunyit 0,5 (K2) & $1 \times 10^{2}$ & $4 \times 10^{4}$ & Tbud & Tbud \\
Kunyit 1 (K3) & $7 \times 10^{1}$ & $9 \times 10^{3}$ & $1 \times 10^{7}$ & Tbud \\
Kunyit 1,5 (K4) & $9 \times 10^{1}$ & $8 \times 10^{3}$ & $1 \times 10^{7}$ & Tbud \\
\hline
\end{tabular}

Ket. Tbud : tidak bisa untuk dihitung

Tabel 2 menunjukan jumlah total bakteri terendah pada awal penyimpanan ( 0 jam) terdapat pada perlakuan $\mathrm{K} 3\left(7 \times 10^{1}\right)$ dan K4 $\left(9 \times 10^{1}\right)$ dan jumlah total bakteri tertinggi pada perlakuan K1 $\left(4 \times 10^{2}\right)$ dan K2 $\left(1 \times 10^{2}\right)$ dimana jumlah bakteri pada sosis ikan dengan berbagai level pemberian tepung kunyit dapat diketegorikan aman dikonsumsi.

Rendahnya jumlah total bakteri pada perlakuan K3 dan K4 disebabkan adanya senyawa aktif pada kunyit yang berfungsi sebagai antimikroba yaitu kurkumin. Kurkumin merupakan senyawa fenol yang bekerja secara efektif menghambat metabolisme bakteri dengan cara memecah protein menjadi molekul sederhana. Hal ini sesuai dengan pernyataan Ginting $d k k$. (2014), cara kerja kunyit sebagai bahan pengawet sangat ditentukan oleh senyawa kurkumin yang dapat memperlambat metabolisme mikroba melalui proses pemecahan protein menjadi molekul sederhana. Pemecahan ini yang dapat memperlambat metabolisme mikroba.

Selain adanya zat antimikroba, penyebab rendahnya jumlah total bakteri karena adanya proses pengukusan sosis dengan suhu $90^{\circ} \mathrm{C}$ selama 20 menit, dimana suhu ini dapat membunuh sebagian bakteri. Hal ini didukung oleh Vergiyana (2014), mikroba dapat dicegah dengan memasak makanan secara menyeluruh. Sedangkan mikroba yang memiliki daya tahan terhadap panas membutuhkan suhu $65^{\circ} \mathrm{C}$ selama 10 sampai 15 menit untuk membunuh sebagian populasi mikroba.

Penyimpanan sosis selama 12 jam menunjukan peningkatan jumlah bakteri yang dapat dilihat pada perlakuan K1 mencapai $8 \mathrm{x}$ $10^{5}$ dan K2 yaitu $4 \times 10^{4}$ lebih banyak jika dibandingkan pada perlakuan K3 yaitu $9 \times 10^{3}$ dan K4 sejumlah $8 \times 10^{3}$ lebih sedikit. Hal ini menunjukan senyawa kurkumin pada perlakuan pemberian tepung kunyit dengan level kunyit $1 \%$ dan $1,5 \%$ mampu menghambat pertumbuhan bakteri sehingga jumlah total bakteri lebih rendah. Menurut Lestarini, $d k k$ (2015), penambahan tepung kunyit $1,5 \%$ telah mampu menghambat pertumbuhan mikroba.

Perlakuan K2 dengan kadar kunyit sebesar $0,5 \%$, kandungan senyawa kurkumin tidak mampu menghambat pertumbuhan bakteri karena jumlah level kunyit lebih sedikit dan sifatnya sebagai antimikroba telah berkurang.Berdasarkan hasil penelitian Cholib, $d k k$. (2013), berkurangnya sifat antimikroba pada rimpang kunyit disebabkan pemanasan dengan menggunakan suhu $90^{\circ} \mathrm{C}$. Sedangkan menurut Harjanti $d k k$. (2003), kurkumin tahan terhadap perlakuan panas dalam waktu singkat, namun akan mengalami kerusakan sepenuhnya pada suhu $180^{\circ} \mathrm{C}$.

Penyimpanan sosis selama 24 jam menunjukan keaktifan kurkumin sebagai antimikroba mulai berkurang. Hal ini disebabkan intensitas cahaya dan suhu ruang selama penyimpanan mengakibatkan degradasi senyawa kurkumin sehingga berkurangnya sifat antimikroba. Menurut Tensiska, $d k k$. (2012), lama penyimpanan pada suhu ruang dan intensitas cahaya menyebabkan degradasi senyawa kurkumin.

Pertumbuhan bakteri meningkat seiring lama penyimpanan, jumlah total bakteri pada semua perlakuan yang disimpan selama 36 jam tidak dapat dihitung sehingga sosis ikan tenggiri pada semua perlakuan tidak layak dikonsumsi, hal ini disebabkan sosis telah 
berlendir dan beraroma asam. Hal ini sesuai dengan hasil penelitian Emma K., dkk. (2014), tampilan fisik sosis selama penyimpanan di suhu ruang menunjukan tekstur lebih lunak, berlendir dan beraroma asam yang menandakan adanya aktifitas mikroba.

\section{Total Koloni Kapang}

Berdasarkan hasil pengamatan sosis ikan tenggiri dengan level tepung kunyit menunjukan adanya perbedaan total koloni kapang pada setiap perlakuan yang disajikan dalam Tabel 3.

Tabel 3. Jumlah total koloni kapang pada sosis ikan tenggiri dengan level tepung kunyit dan lama penyimpanan yang berbeda.

\begin{tabular}{lcccc}
\hline \multirow{2}{*}{$\begin{array}{c}\text { Level tepung } \\
\text { kunyit (\%) }\end{array}$} & \multicolumn{4}{c}{ Lama Penyimpanan (Jam) } \\
\cline { 2 - 5 } & $0(\mathrm{~W} 1)$ & $\begin{array}{c}12 \\
\text { (W2) }\end{array}$ & $\begin{array}{c}\text { (W3) } \\
\text { (W4) }\end{array}$ \\
\hline Kunyit 0 (K1) & $1 \times 10^{2}$ & $1 \times 10^{5}$ & Tbud & Tbud \\
Kunyit 0,5 (K2) & $4 \times 10^{2}$ & $2 \times 10^{5}$ & Tbud & Tbud \\
Kunyit 1 (K3) & $7 \times 10^{1}$ & $6 \times 10^{3}$ & Tbud & Tbud \\
Kunyit 1,5 (K4) & $5 \times 10^{1}$ & $4 \times 10^{3}$ & Tbud & Tbud \\
\hline Ket. Tbud : tidak bisa untuk dihitung
\end{tabular}

Hasil pengamatan sosis ikan tenggiri dengan lama penyimpanan 0 jam menunjukan jumlah total koloni kapang terendah pada perlakuan K4 $\left(5 \times 10^{1}\right)$ dan $\mathrm{K} 3\left(7 \times 10^{1}\right)$ dan tertinggi pada perlakuan K2 $\left(4 \times 10^{2}\right)$ dan K1 $\left(1 \mathrm{x} 10^{2}\right)$, hal ini menunjukan sosis ikan tenggiri pada semua perlakuan aman untuk dikonsumsi. Amannya dikonsumsi sosis ikan tenggiri pada semua perlakuan disebabkan adanya senyawa antifungi yang berasal dari komponen kunyi. Senyawa antifungi yang terkandung di dalam tepung kunyit diduga berasal dari komponen minyak atsiri yang mengandung senyawa metabolit sekunder dalam golongan sesquiterpen yaitu turmerone. Menurut Balbi, $d k k$, (2006) kunyit mengandung senyawa metabolit sekunder dan termasuk ke dalam golongan seskuiterpen yang berfungsi sebagai antifungi. Lanjut ditambahkan oleh Aulifa D.L., $d k k$. (2014) tanaman kunyit (Curcuma domestica Val.)terdapat senyawa turmerone (seskuiterpen)yang memiliki aktivitas antijamur.

Menurut Griffin (1981) senyawa antifungi dapat mengganggu metabolisme energi dalam mitokondria yaitu dalam tahap transfer elektron dan fosforilasi. Terhambatnya transfer elektron akan mengurangi oksigen dan mengganggu fungsi dari siklus asam trikarboksilat.

Sosis ikan tenggiri dengan lama penyimpanan 12 jam terjadi peningkatan jumlah total koloni kapang, dimana jumlah terbanyak terdapat pada perlakuan K2 $\left(2 \times 10^{5}\right)$ dan K1 (1 x 10 $\left.0^{5}\right)$,dibandingkan jumlah kapang yang tumbuh pada perlakuan K3 yaitu $6 \times 10^{3}$ dan K4 sejumlah $4 \times 10^{3}$ lebih sedikit. sehingga sosis ikan tenggiri yang disimpan selama 12 jam masih layak untuk dikonsumsi. Perlakuan K2, tidak mampunya minyak atsiri menghambat pertumbuhan kapang disebabkan sedikitnya pemberian level tepung kunyit.Selain itu, minyak atsiri merupakan senyawa fenol yang tidak larut dalam air namun berpengaruh terhadap suhu dan mudah menguap selama penyimpanan sehingga mengurangi sifat antifungi. Sesuai dengan pendapat Ketaren (1987), minyak atsiri (essential oil, volatilr oil, ethereal oil) adalah minyak yang mudah menguap.

Penyimpanan sosis selama 24 jam jumlah kapang tidak dapat dihitung, dimana pada semua perlakuan koloni kapang saling menyatu dan menutupi permukaan cawan. Pada penyimpanan selama 36 jam jumlah kapang tidak dapat dihitung, dimana pada semua perlakuan koloni kapang telah membentuk hifa dan menutupi permukaan cawan petri.

\section{Uji Sensori \\ Uji Aroma}

Rata-rata penilaian panelis disajikan pada Tabel 4 berikut.

Tabel 4. Uji aroma sosis ikan tenggiri

\begin{tabular}{|c|c|c|c|c|c|}
\hline \multirow{2}{*}{$\begin{array}{l}\text { Level tepung } \\
\text { kunyit }(\%)\end{array}$} & \multicolumn{4}{|c|}{ Lama Penyimpanan (Jam) } & \multirow[b]{2}{*}{ Rerata } \\
\hline & $\begin{array}{c}0 \\
\text { (W1) }\end{array}$ & $\begin{array}{c}12 \\
(\mathrm{~W} 2)\end{array}$ & $\begin{array}{c}24 \\
\text { (W3) }\end{array}$ & $\begin{array}{c}36 \\
\text { (W4) }\end{array}$ & \\
\hline Kunyit 0 (K1) & 4,28 & 3,46 & 1 & 1 & 2,43 \\
\hline Kunyit 0,5 (K2) & 4,1 & 3,624 & 1 & 1 & 2,43 \\
\hline Kunyit 1 (K3) & 4,12 & 3,74 & 1 & 1 & 2,44 \\
\hline Kunyit $1,5(\mathrm{~K} 4)$ & 4,08 & 3,68 & 1 & 1 & 2,46 \\
\hline Rata-rata & $4,15^{\mathrm{c}}$ & $3,63^{b}$ & $1^{\mathrm{a}}$ & $1^{\mathrm{a}}$ & \\
\hline
\end{tabular}

Ket. : Angka yang diikuti huruf yang sama tidak berbeda nyata

Tingginya tingkat kesukaan panelis terhadap sosis ikan pada lama penyimpanan 0 jam (W1) disebabkan adanya aroma khas ikan yang tercium menandakan rendahnya aktifitas 
mikroba. Rendahnya aktifitas mikroba disebabkan adanya senyawa aktif kunyit yang mampu menghambat metabolisme mikroba dengan memecah protein menjadi molekul sederhana. Hal ini sesuai dengan pernyataan Ginting $d k k$. (2014), senyawa aktif kunyit dapat memperlambat metabolisme mikroba melalui proses pemecahan protein menjadi molekul sederhana.

Selain itu, terciumnya aroma khas ikan disebabkan adanya kandungan minyak atsiri kunyit dan komponen volatile pada sosis ikan, kemudian dipengaruhi oleh suhu, sehingga terjadi penguapandan direspon indra penciuman. Menurut Winarno (2002), minyak atsiri bersama komponen volatile pada pangan dapat memperkuat aroma dan rasa. Sedangkan menurut Lestarini, dkk. (2015), suhu selama penyimpanan dapat mempengaruhi penguapan minyak atsiri.

Semakin lama penyimpanan, maka akan tercium aroma busuk. Menurut Winarno, F.G. (2002) proses degradasi protein ditandai dengan timbulnya senyawa $\mathrm{NH}_{3}, \mathrm{H}_{2} \mathrm{~S}$ dan senyawa-senyawa volatile lainnya yang dapat mengindikasikan terjadinya kebusukan.

\section{Uji Warna}

Rata-rata penilaian panelis disajikan pada Tabel 5 berikut.

Tabel 5. Uji warna sosis ikan tenggiri

\begin{tabular}{|c|c|c|c|c|c|}
\hline \multirow{2}{*}{$\begin{array}{l}\text { Konsentrasi } \\
\text { tepung kunyit } \\
(\%)\end{array}$} & \multicolumn{4}{|c|}{ Lama Penyimpanan (Jam) } & \multirow[b]{2}{*}{ Rerata } \\
\hline & $0(\mathrm{~W} 1)$ & $\begin{array}{c}12 \\
(\mathrm{~W} 2)\end{array}$ & $\begin{array}{c}24 \\
(\mathrm{~W} 3)\end{array}$ & $\begin{array}{c}36 \\
(\mathrm{~W} 4)\end{array}$ & \\
\hline Kunyit $0(\mathrm{~K} 1)$ & 4,34 & 3,74 & 1 & 1 & $2,52^{b}$ \\
\hline Kunyit $0,5(\mathrm{~K} 2)$ & 4,20 & 3,64 & 1 & 1 & $2,46^{\mathrm{b}}$ \\
\hline Kunyit 1 (K3) & 4,11 & 3,76 & 1 & 1 & $2,47^{b}$ \\
\hline Kunyit 1,5 (K4) & 3,96 & 3,46 & 1 & 1 & $2,36^{\mathrm{a}}$ \\
\hline Rata-rata & $4,16^{\mathrm{c}}$ & $3,65^{b}$ & $1^{\mathrm{a}}$ & $1^{\mathrm{a}}$ & \\
\hline \multicolumn{6}{|c|}{ 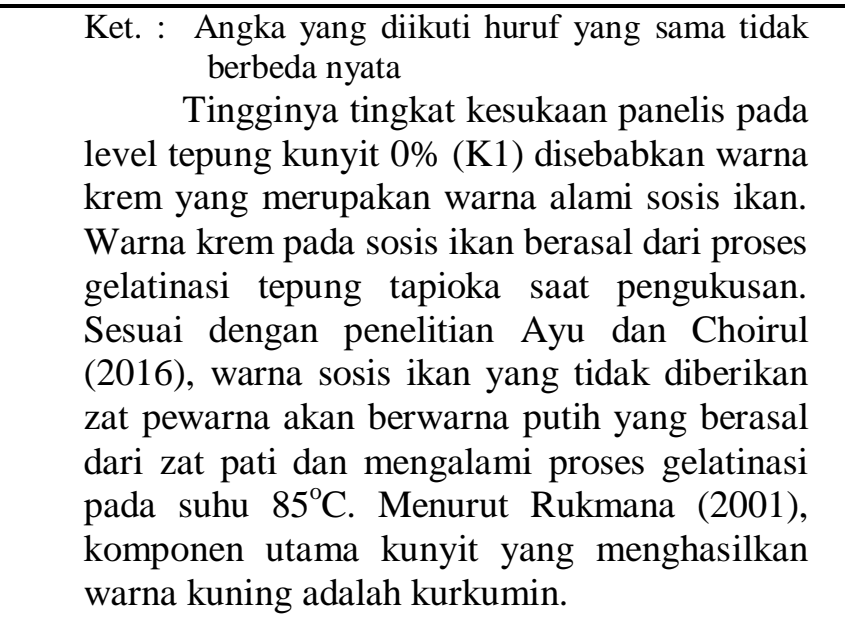 } \\
\hline
\end{tabular}

Hasil penelitian juga menunjukan penilaian panelis tertinggi pada perlakuan lama penyimpanan 0 jam dengan nilai rata-rata 4,16. Hal ini disebabkan warna sosis belum mengalami perubahan. Sedangkan penilaian panelis terendah pada perlakuan lama penyimpanan 24 dan 36 jam dengan nilai 1 . Rendahnya penilaian panelis terhadap warna sosis disebabkan oleh suhu ruang dan cahaya selama penyimpanan. dimana suhu ruang dan cahaya menyebabkan ketidakstabilan senyawa kurkumin sehingga menyebabkan degradasi. Menurut Tensiska, dkk. (2012), warna kuning kurkumin merupakan senyawa yang tidak stabil terhadap cahaya dan suhu. Lama penyimpanan pada suhu ruang dan intensitas cahaya menyebabkan degradasi senyawa kurkumin yang menyebabkan penurunan intensitas warna kuning. Menurut Sidik (1992), bila kurkumin terkena cahaya, akan terjadi degradasi struktur sehingga warna kurkumin berubah.

\section{Uji Tekstur}

Rata-rata penilaian panelis disajikan pada Tabel 6 berikut.

Tabel 6. Uji tekstur sosis ikan tenggiri

\begin{tabular}{|c|c|c|c|c|}
\hline \multirow[b]{2}{*}{$\begin{array}{l}\text { Level tepung } \\
\text { kunyit (\%) }\end{array}$} & \multicolumn{4}{|c|}{ Lama Penyimpanan (Jam) } \\
\hline & 0 (W1) & $\begin{array}{c}12 \\
\text { (W2) }\end{array}$ & $\begin{array}{c}24 \\
\text { (W3) }\end{array}$ & $\begin{array}{c}36 \\
\text { (W4) }\end{array}$ \\
\hline Kunyit 0 (K1) & $3,82^{c}$ & $3,46^{b}$ & $\begin{array}{l}1^{\mathrm{a}} \\
\mathrm{A}\end{array}$ & $\begin{array}{l}1^{\mathrm{a}} \\
\mathrm{A}\end{array}$ \\
\hline Kunyit $0,5(\mathrm{~K} 2)$ & $\begin{array}{c}4,08^{\mathrm{c}} \\
\mathrm{A}\end{array}$ & $\begin{array}{c}3,76^{b} \\
A B\end{array}$ & $\begin{array}{l}1^{\mathrm{a}} \\
\mathrm{A}\end{array}$ & $\begin{array}{l}1^{\mathrm{a}} \\
\mathrm{A}\end{array}$ \\
\hline Kunyit 1 (K3) & $\underset{A}{4,18^{b}}$ & $\underset{B}{4,1^{b}}$ & $\begin{array}{l}1^{\mathrm{a}} \\
\mathrm{A}\end{array}$ & $\begin{array}{l}1^{\mathrm{a}} \\
\mathrm{A}\end{array}$ \\
\hline Kunyit 1,5 (K4) & $\begin{array}{c}4,16^{b} \\
A\end{array}$ & $\begin{array}{c}3,9^{b} \\
B\end{array}$ & $\begin{array}{l}1^{\mathrm{a}} \\
\mathrm{A}\end{array}$ & $\begin{array}{l}1^{\mathrm{a}} \\
\mathrm{A}\end{array}$ \\
\hline
\end{tabular}

Ket. : Angka yang diikuti huruf yang sama tidak berbeda nyata. Huruf kecil dibaca arah horizontal (baris) dan huruf capital dibaca vertical (kolom).

Tingginya tingkat kesukaan panelis terhadap tekstur sosis yang diberi level tepung kunyit $1 \%$ (K3) dengan lama penyimpanan 0 jam (W1) disebabkan sosis yang diberi level tepung kunyit $1 \%$ (K3) memiliki tekstur kenyal dan permukaan sosis halus. Tekstur kenyal pada sosis disebabkan oleh sifat fisik tepung kunyit mudah menyerap air, sehingga mudah mempengaruhi tekstur sosis. Menurut Herlina $d k k$, (2015), pada pengolahan sosis, kadar air sangat berpengaruh terhadap tekstur 
sosis yang dihasilkan. Semakin tinggi kadar air sosis, maka tekstur sosis akan menjadi lembek.

Tingginya tingkat kesukaan panelis terhadap tekstur sosis dengan lama penyimpanan 0 jam (W1) pada level tepung kunyit $1 \%$ (K3) disebabkan senyawa aktif pada kunyit dapat menghambat pertumbuhan mikroba. Terhambatnya pertumbuhan mikroba dapat mengurangi kehilangan kadar air sehingga perubahan tekstur sosis akibat mikroba dapat diminimalisir. Menurut Ayu dan Choiril (2016), kekenyalan dipengaruhi oleh kandungan air, dimana tekstur akan berubah dengan berubahnya jumlah kadar air.

Rendahnya penilaian panelis terhadap tekstur sosis yang disimpan selama 24 jam (W3) dan 36 jam (W4) disebabkan pada permukaan sosis telah berjamur dan berlendir. Menurut Albiner (2002), tanda-tanda kerusakan pangan dapat dilihat dari perubahan kekenyalan, pelunakan tekstur, perubahan kekentalan, pembentukan lendir, pembentukan asam, perubahan warna dan perubahan bau.

\section{Uji Rasa}

Rata-rata penilaian panelis disajikan pada Tabel 7 berikut.

Tabel 7. Uji rasa sosis ikan tenggiri

\begin{tabular}{|c|c|c|c|c|}
\hline \multirow{2}{*}{$\begin{array}{l}\text { Level tepung } \\
\text { kunyit }(\%)\end{array}$} & \multicolumn{4}{|c|}{ Lama Penyimpanan (Jam) } \\
\hline & $\begin{array}{c}0 \\
\text { (W1) }\end{array}$ & $\begin{array}{c}12 \\
\text { (W2) }\end{array}$ & $\begin{array}{c}24 \\
\text { (W3) }\end{array}$ & $\begin{array}{c}36 \\
\text { (W4) }\end{array}$ \\
\hline Kunyit 0 (K1) & $\begin{array}{c}4,3^{\mathrm{c}} \\
\mathrm{B}\end{array}$ & $\begin{array}{c}3,78^{b} \\
\mathrm{AB}\end{array}$ & $\begin{array}{l}1^{\mathrm{a}} \\
\mathrm{A}\end{array}$ & $1^{\mathrm{a}}$ \\
\hline Kunyit 0,5 (K2) & $\begin{array}{c}4,18^{c} \\
A B\end{array}$ & $\begin{array}{c}3,76^{\mathrm{b}} \\
\mathrm{AB}\end{array}$ & $1_{\mathrm{A}}^{\mathrm{a}}$ & $1^{\mathrm{a}}$ \\
\hline Kunyit 1 (K3) & $\underset{\mathrm{AB}}{3,98^{\mathrm{b}}}$ & $\underset{B}{3,86^{b}}$ & $\begin{array}{l}1^{\mathrm{a}} \\
\mathrm{A}\end{array}$ & $\begin{array}{l}1^{\mathrm{a}} \\
\mathrm{A}\end{array}$ \\
\hline Kunyit 1,5 (K4) & $\begin{array}{c}3,88^{c} \\
A\end{array}$ & $\underset{A}{3,44^{\mathrm{b}}}$ & $\begin{array}{l}1^{\mathrm{a}} \\
\mathrm{A}\end{array}$ & $\begin{array}{l}1^{\mathrm{a}} \\
\mathrm{A}\end{array}$ \\
\hline
\end{tabular}

Ket. : Angka yang diikuti huruf yang sama tidak berbeda nyata. Huruf kecil dibaca arah horizontal (baris) dan huruf capital dibaca vertical (kolom).

Tingginya tingkat kesukaan panelis terhadap rasa pada level tepung kunyit 0\% (K1) dengan lama penyimpanan 0 jam disebabkan rasa sosis dengan citarasa ikan merupakan citarasa umum yang dirasakan oleh indra perasa. Penurunan tingkat kesukaan panelis pada lama penyimpanan 24 jam (W3) dan 36 jam (W4) disebabkan menurunnya sifat antimikroba dan antifungi pada kunyit sehingga aktifitas mikroba tidak dapat dihambat dan meningkat signifikan. Menurut
Elly dan Salam (2006), lama penyimpanan pangan disuhu ruang menghasilkan asam yang merupakan hasil samping dari aktfitas mikroba memecah protein sehingga menyebabkan penurunan $\mathrm{pH}$ (mengarah asam).

Tingginya tingkat kesukaan panelis terhadap rasa sosis pada lama penyimpanan 0 jam (W1) dengan level tepung kunyit 0\% (K1) disebabkan senyawa kimia pada ikan memberi sensasi rasa atau taste lebih banyak pada panca indra pengecap, sehingga rasa khas ikan lebih mendominasi pada rasa sosis. Sedangkan pada sosis ikan dengan level tepung kunyit 1,5\% (K4) menunjukan penilaian panelis mengalami penurunan yang disebabkan kunyit memberikan rasa pahit pada sosis. Sesuai dengan pernyataan Joe (2004), kunyit mengandung zat pahit.

Rasa sosis akan berubah dengan semakin lama penyimpanan yang disebabkan adanya aktifitas mikroba. Lama penyimpanan 12 jam (W2) dengan tingkat kesukaan tertinggi pada pemberian level tepung kunyit $1 \%$ (K3) menunjukan kunyit dapat memberi daya awet dengan menghambat pertumbuhan mikroba selama penyimpanan. Menurut BPOM RI (2008), mikroorganisme dapat menyebabkan perubahan-perubahan yang tidak diinginkan seperti penampilan, tekstur, rasa dan bau dari makanan.

\section{Uji Kimia}

Kadar Air

Rata-rata pengujian kadar air disajikan pada Tabel 8 berikut.

Tabel 8. Kadar air (\%) pada sosis ikan tenggiri dengan konsentrasi tepung kunyit dan lama penyimpanan yang berbeda.

\begin{tabular}{|c|c|c|c|c|c|}
\hline \multirow{2}{*}{$\begin{array}{l}\text { Level Tepung } \\
\text { Kunyit (\%) }\end{array}$} & \multicolumn{4}{|c|}{ Lama Penyimpanan (Jam) } & \multirow[b]{2}{*}{ Rerata } \\
\hline & $\begin{array}{c}0 \\
(\mathrm{~W} 1)\end{array}$ & $\begin{array}{c}12 \\
(\mathrm{~W} 2)\end{array}$ & $\begin{array}{c}24 \\
\text { (W3) }\end{array}$ & $\begin{array}{c}36 \\
(\mathrm{~W} 4)\end{array}$ & \\
\hline Kunyit 0 (K1) & 64,76 & 61,62 & 59,4 & 66,71 & $63,12^{\mathrm{a}}$ \\
\hline Kunyit 0,5 (K2) & 65,35 & 62,95 & 61,46 & 65,06 & $63,71^{\mathrm{ab}}$ \\
\hline Kunyit 1 (K3) & 67,23 & 65,19 & 63,35 & 66,39 & $65,54^{\mathrm{ab}}$ \\
\hline Kunyit 1,5 (K4) & 68,98 & 66,37 & 63,48 & 67,33 & $66,54^{\mathrm{b}}$ \\
\hline Rata-rata & $66,58^{\mathrm{b}}$ & $\underset{\mathrm{b}}{64,03^{\mathrm{a}}}$ & $61,92^{\mathrm{a}}$ & $\underset{\mathrm{b}}{66,37}$ & \\
\hline
\end{tabular}

Ket. : Angka yang diikuti huruf yang sama tidak berbeda nyata

Tingginya kadar air pada level tepung kunyit 1,5\% (K4) disebabkan sifat fisik tepung kunyit yaitu higroskopis mudah menyerap air. Sesuai dengan pendapat Brody (2000) bahwa 
produk kering bersifat higroskopis dapat menyerap air, sebaliknya produk basah rentan terhadap hilangnya kadar air. Menurut If'all $d k k$., (2018) menyebutkan penambahan bahan pengisi/pengikat (wortel) berpengaruh sangat nyata terhadap kadar air nugget ikan tuna dan disukai panelis terhadap nilai sensoris warna, aroma, rasa dan tekstur nugget ikan tuna.

Kadar air sosis ikan tertinggi terdapat pada perlakuan lama penyimpanan 0 jam (W1) yaitu $66,58 \%$. Tingginya kadar air pada perlakuan W1 disebabkan sifat fisik tepung kunyit yaitu higroskopis mudah menyerap air. Sesuai dengan pendapat Brody (2000) produk kering bersifat higroskopis dapat menyerap air, sebaliknya produk basah rentan terhadap hilangnya kadar air.

Peningkatan kadar air pada perlakuan lama penyimpanan 36 jam (W4). Peningkatan kadar air disebabkan oleh pertumbuhan mikroba meningkat dan hasil samping dari aktivitas tersebut yaitu terciptanya molekulmolekul air. Sesuai dengan penelitian Puspitasari, $d k k$, (2013) peningkatan kadar air selama penyimpanan disebabkan oleh tingginya laju pertumbuhan mikroba hingga mencapai konstan dan hasil samping aktifitas mikroba yaitu senyawa molekul kecil yang mengandung air.

Rendahnya kadar air sosis pada lama penyimpanan 24 jam (W3) disebabkan menurunnya efektifitas antimikroba dan antifungi pada kunyit. Selain disebabkan oleh pertumbuhan mikroba, penurunan kadar airdiduga disebabkan oleh proses penguapan air dari sosis ke udara, dimana sosis merupakan produk semi basah.

\section{pH}

Tabel 9 berikut.

Rata-rata pengujian $\mathrm{pH}$ disajikan pada

Tabel 9 menunjukan semakin tinggi level tepung kunyit diberikan akan meningkatkan nilai $\mathrm{pH}$. Nilai $\mathrm{pH}$ tertinggi terdapat pada perlakuan level tepung kunyit $1,5 \%$ (K4) yaitu 6,62. Tingginya nilai $\mathrm{pH}$ disebabkan kandungan kunyit yaitu kurkumin bersifat basa. Hal ini sesuai dengan pendapat Rukmana (2001), kurkuminoid yang terkandung dalam kunyit merupakan zat aktif yang bersifat basa pada suasana netral.
Tabel 9. $\mathrm{pH}$ pada sosis ikan tenggiri dengan konsentrasi tepung kunyit dan lama penyimpanan yang berbeda.

\begin{tabular}{|c|c|c|c|c|c|}
\hline \multirow{2}{*}{$\begin{array}{l}\text { Konsentrasi } \\
\text { tepung kunyit } \\
\text { (\%) }\end{array}$} & \multicolumn{4}{|c|}{ Lama Penyimpanan (Jam) } & \multirow[b]{2}{*}{ Rerata } \\
\hline & $\begin{array}{c}0 \\
(\mathrm{~W} 1)\end{array}$ & $\begin{array}{c}12 \\
(\mathrm{~W} 2)\end{array}$ & $\begin{array}{c}24 \\
\text { (W3) }\end{array}$ & $\begin{array}{c}36 \\
(\mathrm{~W} 4)\end{array}$ & \\
\hline Kunyit 0 (K1) & 6.505 & 6.445 & 6.285 & 6.16 & $6,35^{\mathrm{a}}$ \\
\hline Kunyit 0,5 (K2) & 6.535 & 6.465 & 6.42 & 6.255 & $6,42^{\mathrm{a}}$ \\
\hline Kunyit 1 (K3) & 6.63 & 6.555 & 6.5 & 6.375 & $6,51^{\mathrm{b}}$ \\
\hline Kunyit 1,5 (K4) & 6.705 & 6.67 & 6.62 & 6.495 & $6,62^{\mathrm{c}}$ \\
\hline Rata-rata & $6,59^{c}$ & $6,53^{\mathrm{bc}}$ & $6,46^{\mathrm{b}}$ & $6,32^{\mathrm{a}}$ & \\
\hline
\end{tabular}

Hasil penelitian menunjukan penurunan nilai $\mathrm{pH}$ disebabkan suhu ruang selama penyimpanan dapat mempengaruhi struktur senyawa kurkumin, sehingga mengurangi sifat antimikroba. Berkurangnya sifat antimikroba pada senyawa kurkumin menyebabkan peningkatan pertumbuhan mikroba yang juga diikuti peningkatan aktifitas mikroba dalam memecah protein menjadi asam amino dan asam sederhana.

Menurut Siagian (2002), pada produk olahan perikanan, perubahan $\mathrm{pH}$ merupakan indikator kerusakan, yaitu tanda kebusukan. Sedangkan menurut Elly dan Salam (2006), lama penyimpanan pangan di suhu ruang menghasilkan asam yang merupakan hasil samping dari aktfitas mikroba memecah protein sehingga menyebabkan penurunan $\mathrm{pH}$.

\section{Kesimpulan dan Saran}

\section{Kesimpulan}

Berdasarkan penelitian yang telah dilakukan maka dapat disimpulkan sebagai berikut :

1. Sosis ikan tenggiri dengan penggunaan tepung kunyit $1 \%$ telah mampu menghambat pertumbuhan mikroba dan kapang selama 12 jam disuhu ruang.

2. Sosis ikan tenggiri dengan penggunaan tepung kunyit $1 \%$ dan lama penyimpanan 12 jam di suhu ruang dapat mempengaruhi mutu sensori sosis ikan tenggiri dengan tingkat kesukaan yang masih dapat diterima.

3. Penggunaan tepung kunyit $1 \%$ mampu mempertahankan mutu kimia sosis dengan kadar air berkisar 67,23\% - 65,19\% dan 
pH berkisar 6,63 - 6,56 selama 12 jam penyimpanan di suhu ruang.

\section{Saran}

Saran dari hasil penelitian ini adalah perlu dilakukan penelitian lanjutan dengan menggunakan kunyit sebagai pengawet yang dikombinasi dengan penyimpanan pada suhu rendah.

\section{Daftar Pustaka}

Albiner S. 2002. Mikroba Patogen pada Makanan dan Sumber Pencemarannya. Universitas Sumatera Utara. Digitized by USU digital library.

AOAC (Assotiation of Official Analytical Chemist). 1995. Official Methods of Analysis 16 editions. Virginia. AOAC. Inc. Arlington.

Aulifa, D.L., Aryantha, I.N.P. dan Sukrasno. 2014. Aktivitas Anti Jamur Ekstrak Metanol Dari Tumbuhan RempahRempahan. Institut Teknologi Bandung. Jurnal Ilmu-ilmu Hayati dan Fisik. Vol. $16(1): 10-15$

Ayu, G. dan Choirul, A. 2016. Pengaruh Penggunaan Jenis Dan Jumlah Bahan Pengisi Terhadap Hasil Jadi Sosis Ikan Gabus (Channa striata). Universitas Negeri Surabaya.e-journal Boga, Volume 5 (1): $211-228$.

Balbi, P., Becker, Stangarlin, Franzener, Lopes, Mário Schwan, Katia. 2006. Control of Alternaria solani in tomato by Curcuma longa extracts and curcumin In vitro evaluation. Fitopatologia Brasileira journal, Brazil.

BPOM RI. 2008. Pengujian Mikrobiologi Pangan. Info POM Vol. 9 No. 2.

Brody. 2000. Developing new Food Product for Changing Marketplace: Development of Packaging for Product. CRC Press Inc. United States.

Cahyadi, W. 2009. Analisis dan Aspek Kesehatan, Bahan Tambahan Makanan, Edisi kedua. Jakarta : PT Bumi Aksara.

Cholib, F., Mahanani, A., Thamrin, H. 2013. Pengaruh Pemanasan Filtrat Rimpang Kunyit (Curcuma llonga) terhadap Pertumbuhan Koloni Bakteri Coliform
Secara In Vitro. Universitas Negeri Surabaya. LenteraBio Vol. 2 (3): $217-$ 221

Elly, R. dan Salam A.. 2006. Pengaruh Lama Penyimpanan setelah diperah terhadap $\mathrm{pH}$, berat jenis dan jumlah koloni bakteri susu kerbau. Universitas andalas. Padang. Jurnal Peternakan Indonesia., Vol. 11(1): 74-78.

Emma K., Siti K., dan Ari Y. 2014. Deteksi Bakteri Indikator Keamanan Pangan Pada Sosis Daging Ayam Di Pasar Flamboyan Pontianak. Universitas Tanjungpura. Jurnal Protobiont Vol 3 (2): $111-119$.

Ginting, C., Sentosa, G., Ismed, S. 2014. Pengaruh Jumlah Bubuk Kunyit Terhadap Mutu Tahu Segar Selama Penyimpanan Pada Suhu Ruang. USU Medan. Ilmu dan Teknologi Pangan. Jurnal Rekayasa Pangan dan Pertanian Vol 2. (4).

Griffin, D. (1981). Fungal Physiology. New York. John Wiley \& Sons, Inc.

Harjanti S, Purwanti E, dan Sarto, 2003. Zat Warna Kunyit (Kurkumin) sebagai Indikator Titrasi Asam Basa. Prossiding Semnas Teknik Kimia Indonesia.

Herlina, Ikhlas D, dan Andrew R.(2015). Penggunaan Tepung Glukomanan Umbi Gembili (Dioscorea esculenta L.) Sebagai Bahan Tambahan Makanan Pada Pengolahan Sosis Daging Ayam. Universitas Jember. Jurnal Agroteknologi Vol. 09 (2).

If'all, Gobel, M., Fahmi, F., \& Pakaya, I. (2018). Mutu Kimia Dan Organoleptik Nugget Ikan Tuna Dengan Penambahan Berbagai Kombinasi Tepung Wortel. Jurnal Agroindustri Halal, 4(1).

Joe. 2004. Senyawa Kimia Yang Terdapat Pada Tanaman Rempah. UI Press. Jakarta.

Lestarini I.N., Anggarawati N., Nuhriawangsa A.M.P., dan Dewanti R. 2015. Manfaat Penambahan Tepung Kunyit (Curcuma domestica Val) dan Tepung Jahe (Zingiber officinale) Terhadap Kualitas Bakso Itik Afkir dengan Lama 
Penyimpanan yang Berbeda.

Universitas Sebelas Maret. Surakarta. Buletin Peternakan Vol.39 (1) : 9-16.

Purwani E., Retraningtyas E., Widowati D. 2012. Pengembangan Model Pengawet Alami dari Ekstrak Lengkuas (Languas galangal), Kunyit (Curcuma domestica) dan Jahe (Zingiber officinale) sebagai pengganti Formalin pada Daging Segar. FKIP Universitas Sebelas Maret Surakarta. Seminar Nasional IX Pendidikan Biologi. Vol. 9 (1) : 629634.

Puspitasari I., P., Nuhria, W. dan Swastike, W. 2013. Pengaruh Pemanfaatan Kunyit (Curcuma domestica Val.) terhadap Kualitas Mikrobia dan Fisiko-kimia Daging Sapi. Universitas Sebelas Maret. Tropical Animal Husbandry Vol. 2 (1) : 58-64.
Rukmana, R., 2001. Kunyit. Kanisius : Yogyakarta.

Siagian. 2002. Mikroba Patogen pada Makanan dan Sumber Pencemarannya. Digital library, Universitas Sumatera Utara.

Sidik. 1992. Temulawak: Curcuma xanthorriza (Roxb). Jakarta : Yayasan Pengembangan Obat Bahan Alami Phyto Medica.

Tensiska, Nurhadi dan Isfron. 2012. Kestabilan Warna Kurkumin Terenkapsulasi dari Kunyit (Curcuma domestica Val) Dalam Minuman Ringan dan Jelly Pada Berbagai Kondisi Penyimpanan. Universitas Padjadjaran. Vol. 14 (3) : 198 - 206.

Winarno, F.G, 2002. Kimia Pangan dan Gizi. PT. Gramedia. Jakarta. 